\title{
Pengaruh Citra Merek dan Electronic Word of Mouth Terhadap Keputusan Penggunaan Pada Marketplace Lazada di Kabupaten Buleleng
}

\author{
Luh Mega Yuliastuti ${ }^{* 1}$, Gede Putu Agus Jana Susila² \\ 1,2Program Studi Manajemen \\ Universitas Pendidikan Ganesha \\ Singaraja, Indonesia
}

e-mail: luhmegayuliastuti06@undiksha.ac.id ${ }^{* 1}$, agus.jana@undiksha.ac.id²

Pengutipan:

Yuliastuti, Y. M. \& Susila, G. P. A. J. (2021).

Pengaruh Citra

Merek Dan

Electronic Word

Of Mouth

Terhadap

Keputusan

Penggunaan

Pada Marketplace

Lazada

Di Kabupaten

Buleleng. Jurnal

Pendidikan

Ekonomi

Undiksha, 13(1),

22-30

http://dx.doi.org/1

$0.23887 /$ ijpe.v13i

1.32639

\begin{abstract}
Abstrak
Riwayat Artikel Tanggal diajukan: 24 Februari 2021

Tanggal diterima : 19 April 2021

Tanggal dipublikasikan: 25 Juni 2021

Penelitian ini bertujuan untuk menguji pengaruh citra merek dan electronic word of mouth terhadap keputusan penggunaan, pada marketplace Lazada di Kabupaten Buleleng baik secara simultan maupun secara parsial. Desain penelitian yang digunakan dalam penelitian ini adalah kuantitatif kausal. Penentuan sampel dalam penelitian ini menggunakan teknik purposive sampling. Data dikumpulkan dengan menggunakan kuesioner yang akan diuji reliabilitas dan validitasnya dan dianalisis dengan analisis regresi linier berganda. Hasil dari penelitian ini menunjukkan bahwa (1) citra merek dan electronic word of mouth berpengaruh secara simultan terhadap keputusan penggunaan, (2) ada pengaruh citra merek terhadap keputusan penggunaan, (3) ada pengaruh electronic word of mouth terhadap keputusan penggunaan pada marketplace Lazada di Kabupaten Buleleng.
\end{abstract}

Kata kunci: citra merek; electronic word of mouth; keputusan pembelian.

\section{Abstract}

This research aims to examine the effect of brand image and electronic word of mouth on purchasing decisions at Lazada marketplace in Buleleng Regency, both simultaneously and partially. The framework used in this researchs is causal quantitative. Sample is determined by using purposive sampling technique. Data were collected by using a questionnaire which will be tested for its realiability and validity, and will be analyzed by multiple linear regression analysis. The results of this research indicate that (1) brand image and electronic word of mouth have a simultaneous effect on purchasing decisions, (2) brand image has an effect on purchasing decisions, (3) electronic word of mouth has an effect on purchasing decisions at Lazada marketplace in Buleleng Regency.

Keywords : brand image; electronic word of mouth; purchasing decisions.

\section{PENDAHULUAN}

Perkembangan ekonomi digital di Indonesia sebagai wujud dari perkembangan industri perdagangan besar dan eceran serta industri informasi dan komunikasi dengan bantuan internet. Ekonomi digital menandakan pertumbuhan dan perkembangan ekonomi kedepannya, 
ditandai dengan bisnis atau transaksi perdagangan yang menggunakan layanan internet sebagai media komunikasi, kolaborasi dan kerjasama antar perusahaan atau individu (Sayekti, 2018). Dalam hal ini merebaknya internet telah mempengaruhi sektor perekonomian, sehingga bisnis online seperti online shop, e-commerce dan marketplace tumbuh subur di Indonesia. Salah satu bisnis online yang berkembang dengan pesat adalah marketplace.

Marketplace merupakan sebuah tempat atau pasar online yang yang mempertemukan penjual dengan pembeli melalui media internet. Pasar online ini memiliki peran dalam memfasilitasi dan mempromosikan produk serta menjembatani transaksi online antara penjual dengan pembeli. Kehadiran marketplace banyak membantu kebutuhan konsumen. Dalam hal ini konsumen menemukan beraneka ragam produk, seperti fashion, buku, elektronik hingga kebutuhan sehari-hari dengan harga yang bersaing. Mengingat konsumen cenderung menyukai produk yang dibeli secara online karena lebih praktis, modern, dan dapat dilakukan setiap waktu tanpa harus keluar rumah untuk membeli produk yang diinginkan.

Marketplace terbesar di Indonesia adalah Lazada. Lazada merupakan marketplace dari luar negeri yang dimiliki oleh Alibaba Group yang telah berekspansi ke berbagai negara. Di dukung dengan segala informasi yang disajikan didalam aplikasi Lazada yang up to date, dengan itu konsumen akan mendapatkan produk sesuai dengan kriteria yang diinginkan. Selain itu, didalam marketplace ini terdapat toko-toko online terpercaya di seluruh Indonesia sehingga konsumen tidak perlu khawatir terhadap penipuan yang dilakukan oleh black store. Hal ini membuat citra positif yang dapat ditumbuhkan oleh marketplace Lazada. Konsumen akan tertarik membeli produk di tempat yang memiliki citra positif. Kemudian akan membicarakan pengalamannya dalam membeli produk ke orang terdekatnya. Hal ini akan menjadi pertimbangan konsumen dalam membeli produk pada marketplace Lazada.
Banyaknya konsumen yang memilih membeli produk pada marketplace ini membuat marketplace Lazada menduduki posisi top brand dalam kurun waktu dua tahun. Pada tahun 2019 marketplace Lazada mencapai $31.6 \%$ kemudian pada tahun 2020 marketplace Lazada mengalami peningkatan yaitu $0.3 \%$ menjadi $31.9 \%$. Tingginya penjualan produk pada marketplace Lazada dikarenakan oleh tingginya keputusan penggunaan pada marketplace ini. Selain itu, peningkatan jumlah penjualan marketplace Lazada ternyata tidak lepas dari faktor-faktor keputusan penggunaan yang meliputi citra merek dan electronic word of mouth.

Keputusan penggunaan adalah suatu hasil atau keluaran dari proses mental atau kognitif yang membawa pada pemilihan suatu jalur tindakan di antara beberapa alternatif yang tersedia (Firmansyah, 2018). Adanya kemantapan membeli setelah mengetahui informasi produk membuat konsumen merasa mantap dan yakin membeli produk yang telah diketahui informasi produk tersebut secara lengkap pada marketplace Lazada. Tingginya keputusan penggunaan pada marketplace Lazada disebabkan oleh citra merek yang baik serta electronic word of mouth dari konsumen. Hal ini sesuai dengan teori dari (P. Kotler \& Armstrong., 2006) yang menyatakan bahwa konsumen akan membeli merek yang disukai dan mempertimbangkan faktor sikap orang lain yang mempunyai arti penting bagi konsumen. Hasil penelitian dari (Ruhamak \& Rahmadi, 2019) membuktikan bahwa electronic word of mouth, brand image dan brand trust secara simultan berpengaruh terhadap keputusan penggunaan. Hasil penelitian (Mutiara \& Madiawati, 2019) juga membuktikan bahwa electronic word of mouth dan citra merek berpengaruh positif dan signifikan secara simultan terhadap keputusan penggunaan.

Citra merek merupakan salah satu faktor yang mempengaruhi keputusan penggunaan yang dapat dijadikan variabel dalam penelitian ini. Menurut (Susanto \& Wijanarko., 2004) citra merek merupakan suatu merek yang bertujuan untuk meningkatkan citra pemakainya, merek 
harus memiliki kekuatan untuk membangkitkan keinginan konsumen. Dalam hal ini merek yang mampu meningkatkan citra pemakainya akan membuat konsumen untuk membeli produknya. Hubungan emosional yang berhasil ditumbuhkan oleh merek kepada konsumen akan menimbulkan persepsi produk yang memiliki kualitas yang tinggi diikuti dengan reputasi yang baik. Hal ini sesuai dengan teori dari (Tjiptono, 2015) menyatakan bahwa evaluasi produk atau merek akan mengarah kepada keputusan penggunaan. Hasil penelitian Supangkat dan (Supriyatin \& Supangkat, 2017) membuktikan bahwa citra merek berpengaruh signifikan terhadap keputusan penggunaan. Hasil penelitian (Gifani \& Syahputra, 2017) juga membuktikan bahwa citra merek berpengaruh secara signifikan terhadap keputusan penggunaan. Namun, hasil penelitian dari (Prayitno, 2019) menemukan bahwa citra merek berpengaruh tidak signifikan terhadap keputusan penggunaan.

Selain citra merek, electronic word of mouth juga mempengaruhi keputusan penggunaan. Menurut (Schiffman \& Kanuk, 2007) electronic word of mouth merupakan komunikasi yang dilakukan dari mulut ke mulut melalui media internet atau secara online. Dalam hal ini teman atau kerabat merupakan faktor sosial yang mempengaruhi keputusan pembelian konsumen. Hal ini merujuk pada teori dari (Tjiptono \& Diana., 2016) yang menyatakan faktor sosial merupakan salah satu faktor yang mempengaruhi proses keputusan penggunaan. Hasil penelitian (Chanaya \& Sahetapy, 2020)membuktikan bahwa electronic word of mouth memiliki pengaruh yang signifikan dan positif terhadap keputusan penggunaan. Hasil penelitian (Rupayana et al., 2021) juga membuktikan electronic word of mouth berpengaruh positif dan signifikan terhadap keputusan penggunaan. Namun, hasil penelitian (Amin \& Yanti, 2021) menemukan bahwa electronic word of mouth tidak berpengaruh dan tidak signifikan terhadap keputusan penggunaan.

Berdasarkan pemaparan di atas, terdapat ketidaksesuaian antara teori dengan penelitian terdahulu, sehingga diajukan penelitian dengan judul "Pengaruh Citra Merek dan Electronic word of mouth Terhadap Keputusan Penggunaan Pada Marketplace Lazada di Kabupaten Buleleng". Adapun tujuan dari penelitian ini yaitu untuk menguji: (1) pengaruh citra merek dan electronic word of mouth terhadap keputusan penggunaan pada marketplace Lazada di Kabupaten Buleleng, (2) pengaruh citra merek terhadap keputusan penggunaan pada marketplace Lazada di Kabupaten Buleleng, (3) pengaruh electronic word of mouth terhadap keputusan penggunaan pada marketplace Lazada di Kabupaten Buleleng.

\section{Kajian Pustaka Dan Perumusan Masalah} Hubungan Citra Merek dan Electronic word of mouth Terhadap Keputusan Penggunaan

Keputusan penggunaan adalah suatu hasil atau keluaran dari proses mental atau kognitif yang membawa pada pemilihan suatu jalur tindakan di antara beberapa alternatif yang tersedia (Firmansyah, 2018)). Menurut (P. Kotler \& Armstrong, 2008)terdapat beberapa indikator yang dapat digunakan untuk mengukur variabel keputusan pembelian produk diantaranya, (1) kemantapan membeli setelah mengetahui informasi produk; memutuskan membeli karena merek yang paling disukai; (3) membeli karena sesuai dengan keinginan dan kebutuhan; (4) membeli karena mendapat rekomendasi dari orang lain.

Menurut (P. Kotler \& Armstrong., 2006) konsumen akan membeli merek yang disukai dan mempertimbangkan faktor sikap orang lain yang mempunyai arti penting bagi konsumen. Dalam hal ini merek dan sikap orang lain yang dianggap penting oleh konsumen akan mempengaruhi keputusan pembelian. Sejalan dengan Hasil penelitian dari (Ruhamak \& Rahmadi, 2019)membuktikan bahwa electronic word of mouth, brand image dan brand trust secara simultan berpengaruh terhadap keputusan penggunaan. Hasil penelitian (Mutiara \& Madiawati, 2019) juga membuktikan bahwa electronic word of mouth dan citra merek 
berpengaruh positif dan signifikan secara simultan terhadap keputusan penggunaan.

$\mathrm{H} 1$ : Ada pengaruh signifikan citra merek dan electronic word of mouth terhadap keputusan penggunaan pada marketplace Lazada.

\section{Hubungan Citra Merek Terhadap Keputusan Penggunaan \\ Citra merek berkaitan dengan} persepsi konsumen terhadap merek. Menurut (Philip Kotler \& Keller., 2009)keputusan penggunaan adalah keputusan konsumen mengenai preferensi antar merek yang ada di dalam kumpulan pilihan. Indikator citra merek menurut (Davidson \& R, 2010) adalah sebagai berikut, (1) nama baik, (2) pengenalan, (3) hubungan emosional, (4) kesetiaan merek. Menurut (Tjiptono, 2015) menyatakan bahwa evaluasi produk atau merek akan mengarah kepada keputusan penggunaan. Didukung dengan penelitian yang dilakukan oleh Supangkat dan (Supriyatin \& Supangkat, 2017) yang menyatakan bahwa citra merek berpengaruh secara positif dan signifikan terhadap keputusan pembelian. Hasil penelitian (Gifani \& Syahputra, 2017)juga membuktikan bahwa citra merek berpengaruh secara signifikan terhadap keputusan pembelian.

$\mathrm{H} 2$ : Ada pengaruh signifikan citra merek terhadap keputusan penggunaan pada marketplace Lazada.

Hubungan Electronic word of mouth Terhadap Keputusan Penggunaan

Menurut (Schiffman \& Kanuk, 2007) electronic word of mouth merupakan komunikasi yang dilakukan dari mulut ke mulut melalui media internet atau secara online. Menurut (Babin et al., 2005)electronic word of mouth memiliki tiga indikator yang meliputi: (1) kemauan konsumen dalam membicarakan hal-hal positif tentang produk kepada orang lain; (2) rekomendasi produk perusahaan kepada orang lain, dalam hal ini konsumen yang telah merasakan manfaat dari suatu produk akan merekomendasikan kepada orang lain yang dikenalnya; (3) dorongan terhadap teman atau relasi untuk melakukan pembelian terhadap jasa dan produk perusahaan.
Didukung juga oleh (Tjiptono \& Diana., 2016) yang menyatakan faktor sosial merupakan salah satu faktor yang mempengaruhi proses keputusan penggunaan. Hasil penelitian (Chanaya \& Sahetapy, 2020) membuktikan bahwa electronic word of mouth memiliki pengaruh yang signifikan dan positif terhadap keputusan penggunaan. Hasil penelitian (Rupayana et al., 2021) juga membuktikan electronic word of mouth berpengaruh positif dan signifikan terhadap keputusan penggunaan.

H3: Ada pengaruh signifikan electronic word of mouth terhadap keputusan penggunaan pada marketplace Lazada.

\section{METODE}

Jenis penelitian yang digunakan dalam penelitian ini adalah penelitian kuantitatif. Desain penelitian yang digunakan dalam penelitian ini adalah desain penelitian kausal. Subjek dalam penelitian ini adalah konsumen yang membeli produk di marketplace Lazada di Kabupaten Buleleng. Objek penelitian ini yaitu citra merek (X1), electronic word of mouth (X2) dan keputusan penggunaan (Y). Penelitian ini merupakan penelitian sampel. Sampel yang diambil menggunakan metode purposive sampling dengan kriteria responden yang sudah pernah membeli produk pada marketplace Lazada di Kabupaten Buleleng yang berusia 18-45 tahun.

Metode pengumpulan data yang digunakan dalam penelitian ini adalah kuesioner. Jenis kuesioner yang digunakan dalam penelitian ini adalah kuesioner berstruktur (angket tertutup). Salah satu skala yang umum dipakai dalam penyusunan angket adalah skala likert. Metode dan teknik analisis data yang digunakan dalam penelitian ini adalah analisis regresi linier berganda. Sebelum data diolah menggunakan analisis regresi linier berganda, terlebih dahulu harus memenuhi bebas dari asumsi-asumsi klasik, sehingga perlu dilakukan uji asumsi klasik dengan alat bantu komputer Statistical Package for Social Science (SPSS) versi 25,0 for windows. Uji asumsi 
klasik terdiri dari, (1) uji normalitas, mendeteksi apakah residual berdistribusi normal atau tidak yaitu dengan analisis grafik dan uji statistik; (2) uji multikolinearitas, model regresi yang pada umumnya dipakai untuk menunjukkan adanya multikoitas adalah nilai tolerance yang kurang dari 0,10 atau nilai Variance Inflation Factor (VIF) lebih dari pada 10; dan (3) uji heteroskedastisitas, digunakan untuk menguji apakah dalam model regresi terjadi ketidaksamaan variance dari residual satu pengamatan ke pengamatan yang lain dengan analisis grafik dan uji statistik. Pada penelitian ini tidak dilakukan uji autokorelasi karena data ini merupakan data crossection.

Alat analisis yang digunakan dalam penelitian ini adalah analisis regresi linier berganda. Alasan peneliti menggunakan analisis regresi linier berganda karena dalam penelitian ini peneliti menguji pengaruh dari beberapa variabel bebas yaitu citra merek (X1) dan electronic word of mouth $(\mathrm{X} 2)$ terhadap satu variabel terikat yaitu keputusan penggunaan $(\mathrm{Y})$. Koefisien Determinasi (R2) digunakan untuk mengukur seberapa jauh kemampuan model dalam menerangkan variasi variabel terikat. Nilai koefisien determinasi adalah 0 sampai dengan 1. Pengujian hipotesis adalah pengujian terhadap suatu pernyataan dengan menggunakan metode statistik sehingga hasil pengujian tersebut dapat dinyatakan signifikan secara statistik dengan menguji hipotesis menggunakan uji $F$ (uji pengaruh simultan) yang pada dasarnya digunakan untuk menunjukkan apakah semua variabel bebas (independent) yang dimasukkan dalam model mempunyai pengaruh secara bersama-sama terhadap variabel terikat (dependent) dan uji t (uji pengaruh parsial) digunakan untuk menguji signifikansi variasi hubungan antara variabel $X$ dan $Y$, apakah variabel citra merek (X1) dan electronic word of mouth (X2) terhadap variabel keputusan penggunaan $(Y)$.

\section{HASIL DAN PEMBAHASAN}

Hasil

Berdasarkan hasil pengujian menggunakan Statiscal Package Sciences 25,0 for Windows diperoleh hasil pengujian berupa ringkasan hasil output SPSS analisis regresi linier berganda seperti Tabel 1 berikut.

Tabel 1.

Ringkasan Hasil Output SPSS Analisis Regresi Linier Berganda

\begin{tabular}{lllll}
\hline Variabel Bebas & Koefisien & Sig & $\begin{array}{l}\text { Koefisien } \\
\text { Kocelasi }\end{array}$ & $\mathrm{R}^{2}$ \\
\hline Citra Merek & 0,348 & 0,000 & 0,362 & 0,131 \\
Word of Mouth & 0,360 & 0,001 & 0,331 & 0,109 \\
\hline Konstanta & 7,126 & & & \\
Sig F & 0,000 & & & \\
$\mathrm{R}$ & 0,579 & & & \\
$\mathrm{R}^{2}$ & 0,335 & & & \\
\hline
\end{tabular}

Sumber Lampiran Hasil Output SPSS

Struktur hubungan pengaruh citra merek (X1) dan electronic word of mouth (X2) terhadap keputusan penggunaan $(Y)$ dapat dilihat pada Gambar 1.

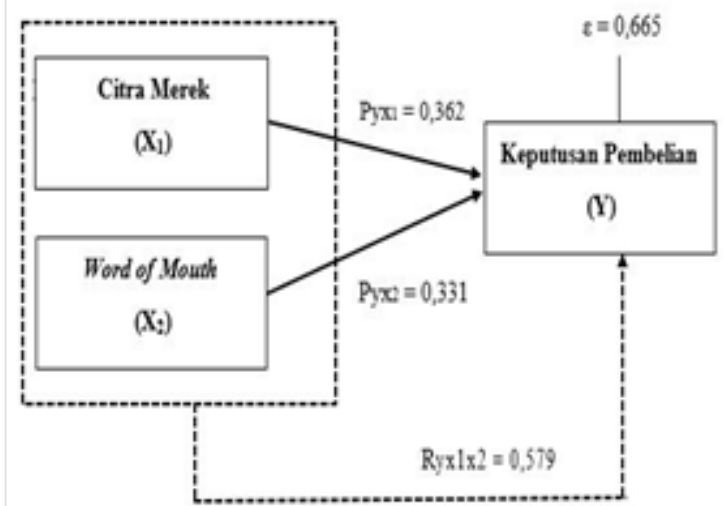

Gambar 1

Struktur Hubungan Pengaruh Citra Merek (X1) dan Electronic word of mouth (X2) Terhadap Keputusan Penggunaan (Y)

Berdasarkan hasil uji regresi linier berganda menunjukkan Ryx1x2 $=0,579$ yang artinya ada pengaruh simultan dari citra merek dan electronic word of mouth terhadap keputusan penggunaan dan R2yx1x2 yang menunjukkan besar sumbangan pengaruh citra merek dan electronic word of mouth terhadap 
keputusan penggunaan sebesar 0,335. Hasil tersebut menunjukkan bahwa hanya sebesar $33,5 \%$. Sedangkan pengaruh dari variabel di luar citra merek dan electronic word of mouth yaitu sebesar $66,5 \%$. Hal ini mengidentifikasi bahwa variabel citra merek dan electronic word of mouth secara bersama-sama berperan dalam meningkatkan keputusan penggunaan. Sehingga hipotesis pertama penelitian diterima.

Berdasarkan hasil uji regresi linier berganda menunjukkan besarnya pengaruh citra merek terhadap keputusan penggunaan dilihat dari hasil Pyx1 $=0,362$, artinya ada pengaruh signifikan citra merek terhadap keputusan penggunaan. Temuan ini memberikan implikasi bahwa citra merek (X1) berperan dalam meningkatkan keputusan penggunaan $(\mathrm{Y})$ dengan hubungan pengaruh sebesar $36,2 \%$. Hasil $\mathrm{P} 2 \mathrm{yx} 1=0,131$ yang artinya dengan besar sumbangan pengaruh citra merek terhadap keputusan penggunaan sebesar $13,1 \%$.

Berdasarkan hasil uji regresi linier berganda menunjukkan besarnya pengaruh electronic word of mouth terhadap keputusan penggunaan dapat dilihat dari hasil Pyx2 =0,331 yang artinya ada pengaruh signifikan electronic word of mouth terhadap keputusan penggunaan. Temuan ini memberikan implikasi bahwa electronic word of mouth (X2) berperan dalam meningkatkan keputusan penggunaan $(Y)$ dengan hubungan pengaruh sebesar $36,2 \%$. Hasil P2yx2 = 0,109 yang artinya dengan besar sumbangan pengaruh electronic word of mouth terhadap keputusan penggunaan sebesar 10,9\%.

Berdasarkan hasil uji regresi linier berganda diperoleh nilai konstanta sebesar 7,126; nilai koefisien regresi citra merek sebesar 0,348; nilai koefisien regresi sebesar word of mouth 0,360 ; dan nilai $\varepsilon$ sebesar 0,665 . Sehingga persamaan regresi diformulasikan sebagai berikut.

\section{$Y=7,126+0,348 \times 1+0,360 \times 2+0,665$}

Persamaan regresi menunjukkan bahwa nilai konstanta 7,126 , ini diartikan sebagai variabel bebas. Apabila variabel bebas (X1) dan (X2) konstan, maka besaran nilai variabel $\mathrm{Y}$ adalah 7,126 . Nilai koefisien citra merek (X1) sebesar 0,348, dapat diartikan bahwa setiap kenaikan citra merek satu satuan maka variabel keputusan penggunaan mengalami kenaikan 0,348 sehingga menjadi 7,474 dengan asumsi bahwa variabel bebas lainnya tetap. Nilai koefisien electronic word of mouth (X2) sebesar 0,360 , dapat diartikan bahwa setiap kenaikan electronic word of mouth satu satuan maka variabel keputusan penggunaan mengalami kenaikan 0,360 sehingga menjadi 7,486 dengan asumsi bahwa variabel bebas lainnya tetap.

Koefisien determinasi digunakan untuk mengetahui seberapa besar pengaruh citra merek dan electronic word of mouth terhadap keputusan penggunaan. Hasil uji koefisien determinasi adalah sebesar 0,321 yang dilihat dari nilai Adjusted $R$ Square. Hasil tersebut berkisar antara 0 sampai 1 yang berarti bahwa dalam penelitian ini citra merek dan electronic word of mouth berpengaruh terhadap keputusan penggunaan sebesar $32,1 \%$, sedangkan $67,9 \%$ dipengaruhi oleh variabel lain yang tidak diteliti dalam penelitian ini.

Berdasarkan hasil uji regresi linier berganda menunjukkan nilai koefisien korelasi berganda sebesar 0,579 dengan nilai $p$-value $0,000<(\alpha) 0,05$ yang menyatakan bahwa $\mathrm{H} 0$ ditolak yang artinya ada pengaruh signifikan secara simultan dari citra merek dan electronic word of mouth terhadap keputusan penggunaan pada marketplace Lazada di Kabupaten Buleleng.

Berdasarkan hasil uji regresi linier berganda menunjukkan citra merek memiliki nilai koefisien korelasi sebesar 0,362 dengan $p$-value $0,000<(\alpha) 0,05$, yang menyatakan bahwa $\mathrm{HO}$ ditolak yang artinya ada pengaruh signifikan secara parsial dari citra merek terhadap keputusan penggunaan pada marketplace Lazada di Kabupaten Buleleng.

Berdasarkan hasil uji regresi linier berganda menunjukkan electronic word of mouth memiliki nilai koefisien korelasi sebesar 0,331 dengan $p$-value $0,000<(\alpha)$ 0,05 yang menyatakan bahwa $\mathrm{H} 0$ ditolak yang artinya ada pengaruh signifikan secara parsial dari electronic word of mouth terhadap keputusan penggunaan pada 
marketplace Lazada di Kabupaten Buleleng.

\section{Pembahasan}

Berdasarkan hasil penelitian yang telah dilakukan menunjukkan bahwa citra merek dan electronic word of mouth berpengaruh positif dan signifikan terhadap keputusan penggunaan pada marketplace Lazada di Kabupaten Buleleng. Hasil penelitian ini sesuai dengan teori ( $P$. Kotler \& Armstrong., 2006) yang menyatakan bahwa konsumen akan membeli merek yang disukai dan mempertimbangkan faktor sikap orang lain yang mempunyai arti penting bagi konsumen. Hal ini sejalan dengan penelitian yang dilakukan oleh (Nuprilianti \& Khuzaini, 2016) yang menemukan bahwa electronic word of mouth dan citra merek secara simultan berpengaruh terhadap keputusan penggunaan.

Mengingat konsumen yang sekarang lebih suka membeli produk secara online di suatu marketplac karena lebih mudah dan cepat. Berbagai produk ditawarkan pada suatu marketplace Lazada seperti fashion, kosmetik, elektronik, buku dan keperluan sehari-hari. Marketplace Lazada berhasil membangun kepercayaan konsumen sehingga konsumen saat ini cenderung membeli produk pada marketplace ini. Konsumen akan percaya membeli produk di suatu marketplace dengan melihat citra mereknya sendiri. Produk-produk pada marketplace ini mudah ditemukan baik yang bermerek maupun tidak bermerek. Pelayanan marketplace Lazada yang memuaskan juga membuat citra mereknya semakin baik dan dikenal dikalangan masyarakat.

Selain itu, electronic word of mouth yang positif juga mempengaruhi keputusan penggunaan pada marketplace Lazada. Konsumen cenderung membeli produk telah mendapat rekomendasi dari teman terdekatnya. Mengingat orang lain terutama orang terdekat memberikan pengaruh dalam menentukan membeli tidaknya suatu produk. Dengan rekomendasi dari teman akan membuat calon konsumen percaya dan menumbuhkan niat untukmembeli produk. Komunikasi ini secara tidak langsung dapat mempromosikan produk-produk pada marketplace Lazada. Dalam hal ini setiap keputusan penggunaan yang dilakukan oleh konsumen tidak terlepas dari citra merek dan electronic word of mouth yang positif pada marketplace Lazada.

Berdasarkan hasil penelitian ini menyatakan bahwa citra merek dan word of mouth berpengaruh positif dan signifikan terhadap keputusan penggunaan pada marketplace Lazada di Kabupaten Buleleng. Hasil penelitian ini sesuai dengan teori (Tjiptono, 2015) menyatakan bahwa evaluasi produk atau merek akan mengarah kepada keputusan penggunaan. Hal ini sejalan dengan penelitian yang dilakukan oleh Supangkat dan (Supriyatin \& Supangkat, 2017) serta (Gifani \& Syahputra, 2017) menemukan bahwa citra merek berpengaruh secara signifikan terhadap keputusan penggunaan.

Dalam aktivitas membeli produk, ada beberapa hal yang dipertimbangkan konsumen di Kabupaten Buleleng dalam membeli produk di marketplace Lazada. Salah satunya ialah memandang citra perusahaan dari marketplace tersebut. Citra perusahaan merupakan persepsi konsumen terhadap suatu produk. Citra perusahaan mencakup popularitas, kredibilitas, dan jaringan perusahaan. Sebuah merek dapat memikat hati konsumen dengan catatan harus memiliki reputasi yang baik, sehingga berapapun harga yang dilabelkan dalam merek tersebut akan tetap membuat konsumen untuk membelinya. Marketplace Lazada memiliki citra yang baik dikalangan masyarakat.

Melalui marketplace ini, perusahaan mampu memberikan citra perusahaan yang baik dengan memberikan pelayanan yang sesuai dengan kebutuhan dan keinginan konsumen. Adapun pelayanan yang diberikan seperti kerjasama dengan jasa ekpedisi dalam pengiriman barang, menerima review konsumen di kolom komentar pada website, menyediakan berbagai produk berupa foto di website, dan menanggapi dengan cepat permintaan konsumen. Foto-foto produk yang ditampilkan pada website Lazada sesuai dengan bentuk aslinya ketika sudah sampai di tangan konsumen. Hal ini akan 
menimbulkan persepsi yang positif terhadap marketplace Lazada.

Hubungan emosional, yaitu

hubungan emosional yang terjadi antar merek dengan pelanggan. Hubungan emosional yang berhasil ditumbuhkan oleh merek kepada konsumen akan menimbulkan persepsi produk yang memiliki kualitas yang tinggi diikuti dengan reputasi yang baik. Hal ini timbul atas reputasi merek yang baik sehingga kepercayaan tumbuh di dalam benak konsumen. Semakin positif citra merek berpengaruh terhadap peningkatan keputusan penggunaan produk pada marketplace Lazada. Citra merek mendukung konsumen untuk menentukan keputusannya dalam membeli produk.

Berdasarkan hasil penelitian ini menyatakan bahwa electronic word of mouth berpengaruh positif dan signifikan terhadap keputusan penggunaan pada marketplace Lazada di Kabupaten Buleleng. Hasil penelitian ini sesuai dengan teori dari (Tjiptono \& Diana., 2016) yang menyatakan faktor sosial merupakan salah satu faktor yang mempengaruhi proses keputusan penggunaan. Hal ini sejalan dengan penelitian yang dilakukan oleh (Alvionita \& Prijati, 2017) yang menemukan electronic word of mouth berpengaruh positif dan signifikan terhadap keputusan penggunaan.

Hadirnya komunikasi electronic word of mouth mengenai marketplace Lazada menentukan pilihan konsumen dalam membeli produk. Konsumen yang pernah membeli produk di marketplace Lazada akan memberikan informasi kepada orangorang terdekatnya, baik teman, keluarga maupun rekan kerja. Hal ini akan mempengaruhii calon konsumen membeli atau tidaknya produk tersebut. Konsumen yang merasa puas membeli produk di marketplace Lazada akan menceritakan pengalamannya sesuai dengan apa yang dirasakan serta merekomendasikan produk tersebut kepada orang-orang terdekatnya. Sehingga orang-orang yang mendapat informasi tersebut akan tertarik membeli produk di marketplace Lazada. Hal ini timbul pula dikarenakan apa yang ditawarkan serta pelayanan yang diberikan oleh marketplace kepada konsumen dapat memuaskan konsumen. Semakin sering konsumen menceritakan hal-hal yang positif terkait produk di marketplace Lazada semakin banyak pula yang tertarik membeli produk di marketplace ini. Seperti halnya konsumen di Kabupaten Buleleng yang memiliki minat tinggi membeli produk secara online khususnya di marketplace Lazada. Sehingga terjadi peningkatan keputusan penggunaan pada marketplace Lazada.

\section{SIMPULAN DAN SARAN \\ Simpulan}

Berdasarkan hasil penelitian yang telah dilakukan, diketahui terdapat pengaruh secara simultan maupun parsial citra merek dan word of mouth terhadap keputusan pembelian pada marketplace Lazada di Kabupaten Buleleng. Simpulan penelitian yang telah dilakukan sebagai berikut. (1) Citra merek dan word of mouth berpengaruh positif dan signifikan terhadap keputusan pembelian pada marketplace Lazada di Kabupaten Buleleng. (2) Citra merek berpengaruh positif dan signifikan terhadap keputusan pembelian pada marketplace Lazada di Kabupaten Buleleng. (3) Word of mouth berpengaruh positif dan signifikan terhadap keputusan pembelian pada marketplace Lazada di Kabupaten Buleleng.

\section{Saran}

Berdasarkan simpulan yang telah dipaparkan, penulis dapat mengajukan beberapa saran bagi perusahaan maupun bagi peneliti selanjutnya, diantaranya: (1) Bagi marketplace Lazada diharapkan dapat memenangkan persaingan pasar di bidang pasar online, marketplace Lazada harus mempertahankan citranya yang positif serta informasi up to date agar dapat menarik perhatian konsumen yang ingin membeli produk secara online. (2) Bagi masyarakat diharapkan marketplace Lazada dapat memberikan suatu program yang mampu menunjang tingginya tingkat keputusan pebelian seperti CSR kepada masyarakat. (3) Bagi peneliti selanjutnya, hasil penelitian ini dapat dijadikan referensi dalam melakukan penelitian terkait keputusan pembelian. Variabel yang dapat digunakan seperti kepercayaan, kualitas 
informasi, keamanan, promosi, harga serta dapat menggunakan teknik analisis yang berbeda seperti analisis jalur maupun moderasi.

\section{DAFTAR PUSTAKA}

Alvionita, V., \& Prijati. (2017). PENGARUH WORD OF MOUTH, CITRA MEREK DAN HARGA TERHADAP KEPUTUSAN PEMBELIAN CHATIME. Urnal IImu Dan Riset Manajemen, 6(3), 1-16.

Amin, A. M., \& Yanti, R. F. (2021). Pengaruh Brand Ambassador, EWOM, Gaya Hidup, Country of Origin dan Motivasi Terhadap Keputusan Pembelian Produk Skincare Korea Nature Republic. Jurnal Inovasi Bisnis Dan Akuntansi, 2(1), 1-14.

Babin, B. ., Laroche, M., Lee, Y. K., Kim, E. J., \& Griffin, M. (2005). Modeling consumer satisfaction and word-ofmouth: restaurant patronage in Korea. Journal of Services Marketing.

Chanaya, N., \& Sahetapy, W. L. (2020). Pengaruh Brand Experience Dan Electronic Word Of Mouth (E-Wom) Terhadap Keputusan Pembelian Pada Jasa Wedding Organizer Perfect Moment. AGORA, 8(1), 1-6.

Davidson, W., \& R, et. al. (2010). Retailing Management. Edisi Keenam. New York: John Willey \& Sons.

Firmansyah, M. A. (2018). Perilaku Konsumen (Sikap dan Pemasaran). Surabaya: CV Budi Utama.

Gifani, A., \& Syahputra, S. (2017). Pengaruh Citra Merek Terhadap Keputusan Pembelian Produk Smartphone Oppo Pada Mahasiswa Universitas Telkom. Majalah Bisnis Dan IPTEK, 10(2).

Kotler, P., \& Armstrong, G. (2008). Principles of Marketing. New jersey: Pearson Education.

Kotler, Philip, \& Keller., K. L. (2009). Manajemen Pemasaran Jilid 1. Edisi Ketiga Belas Terjemahan Bob Sabran, MM. Jakarta: Erlangga.

Mutiara, \& Madiawati, P. N. (2019). Pengaruh Electronic Word Of Mouth Dan Citra Merek Terhadap Keputusan Pembelian Nature Republic Aloe Vera
92\% Soothing Gel. E-Proceeding of Management, 6(1), 1099-1106.

Nuprilianti, N. P., \& Khuzaini. (2016). Pengaruh PersonalSelling, Brand Image, Word of Mouth Terhadap KeputusanPembelian: Mobil. Jurnal IImu Dan Riset Manajemen, 5(2).

Prayitno, B. B. (2019). Pengaruh Kualitas Produk, Harga, Citra Merek dan Word of Mouth Terhadap Keputusan Pembelian Yamaha R15. Jurnal IImu Dan Riset Manajemen, 8(2).

Ruhamak, M. D., \& Rahmadi, A. N. (2019). (2019). "Pengaruh E-WOM, Brand Image dan Brand Trust Terhadap Keputusan Konsumen (Studi Kasus Pada Lembaga Kursus Fajar English Course Pare Kediri)." , 7(2), . Jurnal Bisnis Dan Manajemen Islam, 7(2), 233-246.

Rupayana, I. K., Suartini, I. W., \& Mashyuni, I. (2021). Pengaruh Kualitas Produk, Impulse Buying dan Electronic Word of Mouth (EWOM) terhadap Keputusan Pembelian pada Produk Smartphone Merek Oppo di Kota Denpasar. Jurnal Manajemen, Kewirausahaan, Dan Pariwisata, 1(1), 233-247.

Sayekti, N. W. (2018). Perkembangan Ekonomi Digital di Indonesia. Info Singkat, 5(4), 19-24.

Schiffman, L., \& Kanuk, L. (2007). Perilaku Konsumen, Edisi Ketuju. Jakarta:PT. Index.

Supriyatin, \& Supangkat, A. H. (2017). Pengaruh Citra Merek, Kualitas Produk, Harga Terhadap Keputusan Pembelian Tas di Intako. Jurnal IImu Dan Riset Manajemen, 6(9), 1-19.

Susanto, A. ., \& Wijanarko., H. (2004). Power Branding Membangun Merek Unggul dan Organisasi Pendukungnya. Jakarta: PT Mizan Publika.

Tjiptono, F. (2015). Strategi Pemasaran. Edisi keempat. Yogyakarta: ANDI.

Tjiptono, F., \& Diana., A. (2016). Pemasaran Esensi \& Aplikasi. Yogyakarta: ANDI. 